九州大学学術情報リポジトリ

Kyushu University Institutional Repository

EMBOLEMIDAE OF JAPAN, WITH DESCRIPTION OF A NEW SPECIES OF EMBOLEMUS FROM HACHI JO ISLAND (HYMENOPTERA, BETHYLOIDEA)*

Hirashima, Yoshihiro

Yamagishi, Kenzo

https://doi.org/10.5109/2366

出版情報: ESAKIA. 9，pp.25-30，1975-12-15. Hikosan biological laboratory，Faculty of Agriculture, Kyushu University

バージョン :

権利関係 : 


\title{
EMBOLEMIDAE OF JAPAN, WITH DESCRIPTION OF A NEW SPECIES OF EMBOLEMUS FROM HACHI JO ISLAND (HYMENOPTERA, BETHYLOIDEA)*
}

\author{
Yoshiniro Hirashima** and Kenzou Yamagishi \\ Entomological Laboratory, Faculty of Agriculture, \\ Kyushu University, Fukuoka 812, Japan
}

\begin{abstract}
Synopsis Brief descriptions of Embolemus and Embolemus walkeri Richards are made, new localities of the latter are recorded, and a new species Embolemus hachijoensis is described from Japan (Hachijo Island).
\end{abstract}

The family Embolemidae are represented in the Palaearctic Region by a single genus Embolemus Westwood, 1833. It has been represented in Japan by a single species, Embolemus walkeri Richards, which also occurs in China. Embolemus walkeri is a species of considerable rarity; in Japan, only two female and three male specimens have been put on record so far since it was first discovered in 1950. Very recently, however, Mr. H. Makihara of Kyushu University and the junior author collected a number of male specimens of this species from Kyushu, respectively. These are here recorded in addition to a single male specimen from Tsushima taken in 1959 which has been kept in our collection.

The biology of Embolemus walkeri is still unknown, but the first

Contribution from the Entomological Laboratory, Faculty of Agriculture, Kyushu University, Fukuoka (Ser. 3, No. 29), and that from the Hikosan Biological Laboratory, Faculty of Agriculture, Kyushu University, Hikosan (Ser. 2, No. 50).

Also, Hikosan Biological Laboratory, Faculty of Agriculture, Kyushu University, Hikosan, Fukuoka 824-07, Japan, 
specimen of this species (female) in Japan was taken in nest of Myrmica sp. by Dr. Y. Kurosawa (National Science Museum, Tokyo). Thus, it is supposed to be parasitic on that ant.

It is very interesting to report here the occurrence of a second species of Embolemus from Japan, which is a new species discovered from Hachijo Island, an islet in the Pacific Ocean about $300 \mathrm{~km}$ south of Tokyo. Two male specimens of this new species were collected by Mr. M. Shiga and the senior author in 1964. Description of the new species is given in this paper.

Embolemus of the Palaearctic Region now includes four species, i. e., two European (Embolemus ruddii Westwood and Embolemus antennalis (Kieff er)), one Sino-Japanese (Embolemus walkeri Richards) and one Japanese (Embolemus hachijoensis Hirashima et Yamagishi, sp. n.).

According to Richards (1939), the Embolemidae are recorded or specimens of them were taken, outside the Palaearctic Region, from the United States, Chile, Java and S. Africa. The senior author has examined a number of male specimens of Embolemus from New Guinea in the Bishop Museum (Honolulu) collection.

Acknowledgements: We are grateful to Mr. Hiroshi Makihara of Kyushu University for his endeavor in finding Embolemus from Mt. Hikosan, Kyushu.

Genus Embolemus Westwood, 1833

Type-species : Embolemus ruddii Westwood, 1833. A British species,

The following is an addition to the description of the genus made by Richards (1939).

Ocelli absent in female, present in male; eyes small in female, large in male; antennae lo-segmented; scape of female stout and elongate (about as long as next three segments taken together), that of male variable in length but not exceeds length of head; mandibles quadridentate ; abdomen petiolate, petiole very short in both sexes; 1st sternum of female with a large, deep and hairy excavation in middle.

The last mentioned structure of the female wasp may be functional in relation to its habit.

Embolemus walkeri Richards, 1951

Embolemus walkeri Richards, 1951, Ann. Mag. Nat. Hist. ser. 12, 4(44): 814-815, 
female (China (near Ning-Po, Da-Laen-Saen) and Japan (Akai, Minato-mura, Fukushima Prefecture)).

Embolemus walkeri: Yasumatsu, 1954, Gensei, 3(1/2): 1-2, illustration and redescription (in Japanese) of female (Mt. Kuishi, $1100 \mathrm{~m}$, Tosa-gun, Kochi Prefecture).

Embolemus walkeri: Yasumatsu, 1960, Esakia, (1) : 24-25, pl. 6, description and illustration of male (two localities from Shikoku (Sugitate and Mt. Saragamine)).

In Japan, this species has been collected from Fukushima (Honshu) and Ehime (Shikoku) Prefectures. We have seen five specimens of male from three more localities as follows: 1 male, Taterayama, Tsushima, 27. ix. 1959 (T. Hidaka, H. Kamiya, K. Morimoto and T. Kawarabata) ; 3 males, near summit of Mt. Hikosan, 1200 m, Fukuoka Prefecture, 5-6. x. 1972 (H. Makihara); 1 male, Kamiozoegawa, near Hokuzan Dam, Saga Prefecture, 25. ix. 1973 (K. Yamagishi). Thus, this species is known in Japan from Honshu, Shikoku, Kyushu and Tsushima.

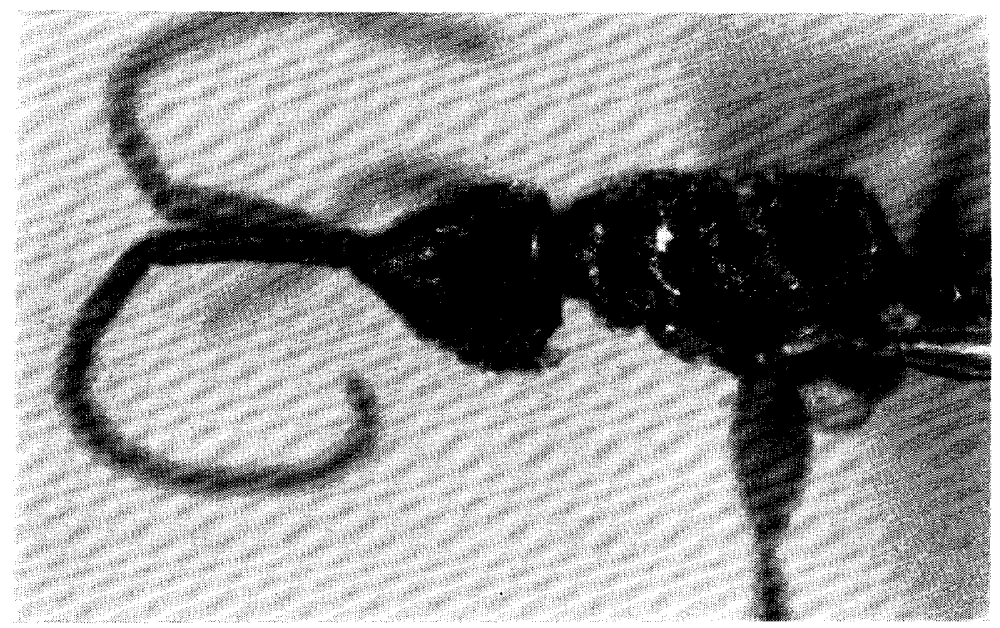

Fig. 1. Female of Embolemus walkeri Richards, Head and thorax.

The following is an addition to the description of male given $\mathbf{b} \mathbf{y}$

$$
\text { palpi of male long, relative length s }
$$
in three specimens formerly examined by Yasumatsu from Ehime Prefecture, 


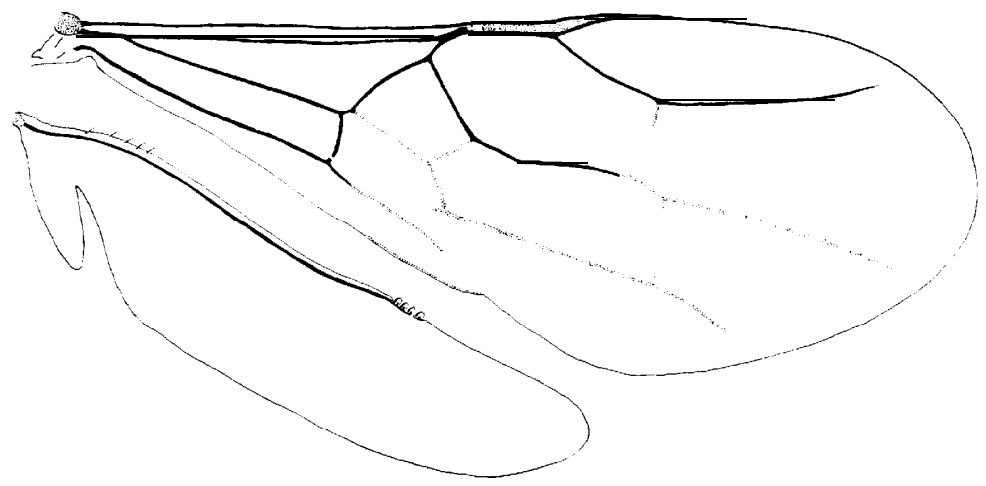

Fig. 2. Male wing of Embolemus walkeri Richards.

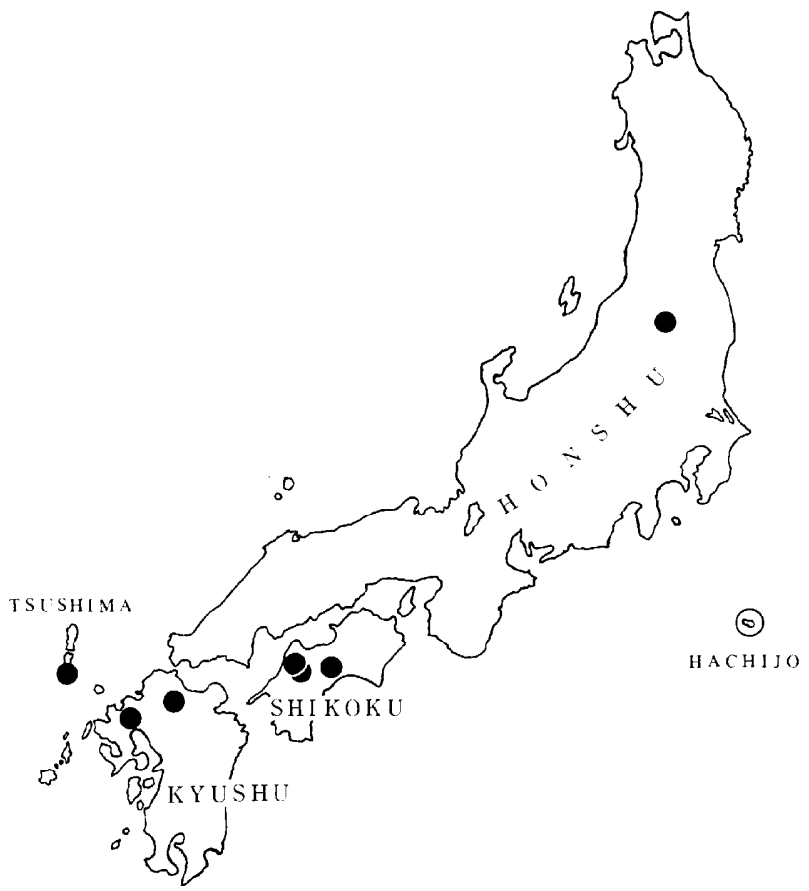

Fig. 3. Location of the collecting sites of two species of Embolemus in Japan. Black dot: E. walkeri. Circle : E. hachijoensis. 
Shikoku, from scape to 10th segment,

6: 2: 15.5: 15: 14.5: 14: 13: 12.5: 12: 13,

6: 2: 15.5: 14.5: 14: 13: 12: 11.5: $11: 11.5$,

5.5: 1.8: 13.5: 13.5: 13: 12: 11.5: 11.5: $11: 12(25=1 \mathrm{~mm})$

although he says that they are 6: 1.5: 15: 14: 13: 13: 12: 12: 10: 12 . Color of body fairly variable; in female head and abdomen blackish-tinged in a paratype female from Fukushima Pref., but body uniformly red in another specimen from Kochi Pref., ; in male, thorax and abdomen blackish brown to yellowish brown, and legs pale yellowish brown to distinctly yellowish, with hind tibiae and tarsi often darkened; head of male usually shining black.

The wings of the male of this species are illustrated again in this paper in order to show the venation of the fore wing and the hamuli of the hind wing.

\section{Embolemus hachijoensis sp. n.}

This species is described from the male sex only.

The male of this species is easily separable from that of Embolemus walkeri by the size smaller and the scape subequal to the 3rd segment in length (in walkeri, the scape is less than one-half of the 3rd segment). It is further characterized in having the mesoscutum finely reticulate

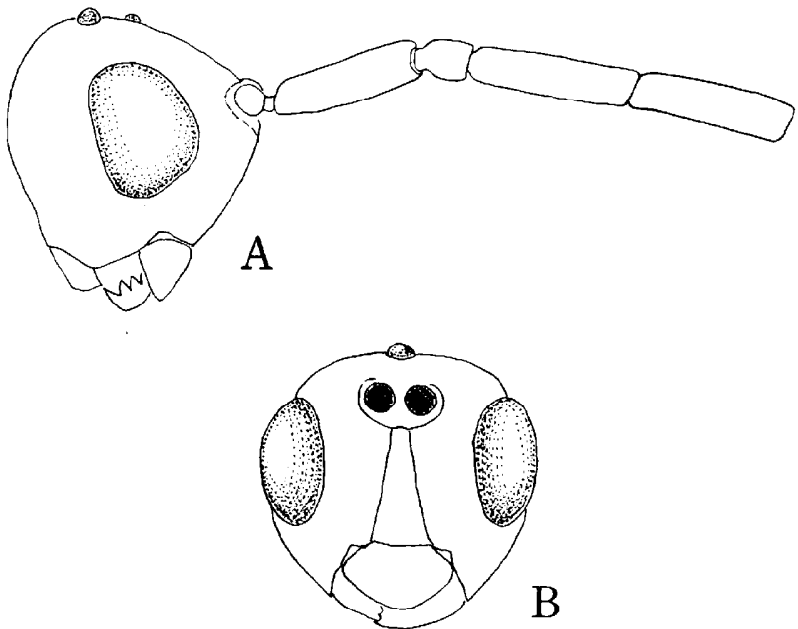

Fig. 4. Male head of Embolemus hachijoensis sp. $\mathrm{n}$.

A: Side view, with four basal antennal segments.

B: Front view. 
and dull, and the propodeum less coarsely sculptured with a pair of median, longitudinal carinae which extend from the base to the apex of propodeum. In walkeri, such longitudinal carinae are absent.

Male: Length slightly over $2 \mathrm{~mm}$, antennae slightly longer than length of body.

Head shining blackish brown; mandibles and clypeus yellowish (in one specimen clypeus not distinctly yellowish); antennae pale brown like walkeri but slightly paler ; thorax brown; legs pale yellowish brown like walkeri or more yellowish, but hind tibiae and tarsi not darkened; wings slightly smooky because of dense pale hairs like walkeri; abdomen shining yellowish brown.

Head similar to that of walkeri in shape and sculpture (smooth, shining with microscopical fine punctures) ; relative lengths of antenna1 segments, from scape to 10 th segment, 6: $2: 7: 6.5: 6: 6: 5.5: 5.2: 5: 7.2(25=1 \mathrm{~mm})$; maxillary palpi short, relative lengths of apical four segments, from 3rd to 6th, 2.8 : 3.2 : $1.2: 2(20=0.5 \mathrm{~mm})$; mesoscutum microscopically reticulate, nearly dull (smooth, shining, with microscopical fine punctures in walkeri); propodeum slightly shorter than one-half of length of thorax, coarsely sculptured with weak rugae; as seen from above, propodeum with a pair of median, longitudinal, rather strong carinae which extend from base to apex of propodeum; metasoma, as seen from above, long elliptical (with both ends pointed), smooth, impunctate and highly shining.

Type material : Holotype male (Type No. 2046, Kyushu Univ.) and 1 paratopotype male, Sueyoshi, Hachijo Island, 28. v. 1964 (Y. Hirashima and M. Shiga).

Type depository : Entomological Laboratory, Faculty of Agriculture, Kyushu University, Fukuoka.

Distribution: Endemic to Hachijo Island, about $300 \mathrm{~km}$ south of Tokyo, Japan.

\section{Literature}

Richards, 0. W. 1939. The British Bethylidae (s. l.) (Hymenoptera). Trans. R. ent. Soc. Lond., 89 (8): 185-344 (The British Emboleminae, pp. 293-297).

— 1951. New species of Bethyloidea (Hymenoptera). Ann. Mag. Nat. Hist., ser. 12, 4 (44) : 813-820.

Yasumatsu, K. 1954. Note on Embolemus walkeri Richards, Gensei, 3(1/2): 1-2 (In Japanese).

- 1960. Notes on two species of Japanese Bethyloidea (Hymenoptera). Esakia, (1) : 21-25, 1 pl. 